\title{
LEOPOLDO ALAS “CLARÍN”, ENTRE LA TRADICIÓN ÁUREA Y LA INNOVACIÓN NATURALISTA
}

\author{
Mariano Nicolás Saba \\ CONICET - Universidad de Buenos Aires \\ marianosaba@gmail.com
}

RESUMEN / ABSTRACT

Como crítico privilegiado de finales del siglo XIX, Leopoldo Alas "Clarín" muestra en sus opiniones sobre el teatro del Siglo de Oro cierta tensión inevitable entre tradición e innovación. Un análisis preciso sobre el asunto revela en él la funcionalidad de las metáforas relativas al campo semántico de la "enfermedad". Tales imágenes -en consonancia con algunos juicios contemporáneos de Pardo Bazán- ilustran la significativa tensión entre el canon literario nacional y el advenimiento foráneo de la experimentación naturalista. Las formas retóricas de esa contienda pueden hallarse justamente en la imbricación de las lecturas clarinianas sobre el drama del Imperio español con las metáforas de la enfermedad, tan recurrentes en el naturalismo ficcional.

Palabras Clave: Leopoldo Alas, teatro del Siglo de Oro, naturalismo, crítica del siglo XIX.

As a privileged critic of the late nineteenth century, Leopoldo Alas "Clarin" shows in his views about the Golden Age theatre certain inevitable tension between tradition and innovation. An accurate analysis reveals in that issue the functionality of metaphors related to semantic field of "disease". Such images -in line with some contemporary judgments of Pardo Bazán-illustrate the significant tension between the national literary canon and foreign advent of naturalistic experimentation. Rhetorical forms of that clash can be found precisely in the overlapping of Clarin's readings on the drama of the Spanish Empire and metaphors of disease, often present in the fictional naturalism.

KEYWORDS: Leopoldo Alas, Golden Age theater, naturalism, Nineteenth Century critics. 
"Cada vez que Calderón, Lope o Tirso, Alarcón, Rojas o Moreto hablan en nuestros coliseos, siente el alma el orgullo noble del patriotismo... Pero nada de eso es lo que hoy ha de buscar la musa dramática, si quiere atraer de nuevo la atención del público que la abandona".

Leopoldo Alas "Clarín", "Del teatro", Solos de clarín

"Lo que cuenta en las cosas dichas por los hombres no es tanto lo que los hombres hayan pensado antes o después, sino lo que desde el comienzo las sistematiza y las vuelve, para el resto del tiempo, indefinidamente accesibles a nuevos discursos y abiertas a la tarea de transformarlas".

Michel Foucault, El nacimiento de la clínica

\section{A MODO DE INTRODUCCIÓN}

Algunas de las ideas que me propongo abordar aquí son el resultado de combinar una serie de especulaciones provisorias que he venido exponiendo de manera parcial y autónoma en varios tratamientos previos. Mi objetivo es cohesionar los distintos asedios que me han convocado en torno a la recepción clariniana del teatro áureo y a su reacción crítica poblada de metáforas relativas a la enfermedad. Busco afirmar, entonces, la hipótesis de que la crítica de Leopoldo Alas "Clarín" soslaya un análisis directo del vínculo entre el siglo XIX y la tradición áurea, pero compensa ese vacío con una referencia al canon barroco que aparece de forma recurrente en buena parte de sus artículos y ensayos principales. Sus modulaciones diversas de esa tensión entre el panteón tradicional del Siglo de Oro y la necesaria innovación de la praxis dramática -ya sea del texto, como también de la escena- ocupan buena parte de las argumentaciones que aparecen en este artículo. La disposición de los temas que aquí postulo comienza por una indagación en los modelos de actuación deseables según Alas. Este eje permite ingresar a la cuestión del actor como vehículo "transparente" de la literatura dramática y, específicamente, al caso de Rafael Calvo, intérprete decimonónico fundamental para la consolidación del teatro barroco como monumento fundacional de la identidad hispánica. Como aludiré más adelante, Alas le dedica un ensayo que resulta valioso por "escenificar" - a través de la figura del legendario actor- la contienda entre tradición e innovación. Y en esta línea -y en la coincidencia con algunas opiniones contemporáneas de Pardo Bazán- resulta interesante capturar los 
modos metafóricos en que la "enfermedad" pasa a ser explicativa de la puja entre el pasado literario y la innovación naturalista.

\section{HACIA UN MODELO CLARINIANO DE LA ACTUACIÓN}

Leopoldo Alas fue en su tiempo uno de los críticos más determinantes para la jerarquización de las expresiones culturales dentro del teatro español. Como tal, algunas de sus opiniones sobre la actuación debieron definir ciertos rasgos decisivos en cuanto al modelo de artista deseable para su época. Y en este sentido, varios de sus artículos periódicos no solo sirven para recuperar la valoración de figuras como Rafael Calvo, María Guerrero o Sarah Bernhardt, sino también para actualizar -en un campo distinto de lo literario- la tensión que "Clarín" padecería siempre en el forcejeo entre los vectores de la tradición y la renovación del arte dramático.

Mucho tuvo que ver el aire "modernizador" del naturalismo en su perspectiva de la escena española de fines de siglo. Pero como Pardo Bazán, Alas no adhirió a las propuestas de Zola sino a través de un prisma "español", capaz de descentrar el carácter materialista de la ortodoxia francesa, y de valorar sus técnicas y sus temas por fuera de su dogmatismo. Por esto considero que su cosmovisión respecto de lo teatral se explica en buena parte a través del contacto que ciertas recurrencias naturalistas tuvieron con su mirada de la escena española. De hecho, el campo semántico de la "enfermedad" reaparece una y otra vez en los juicios clarinianos sobre la decadencia teatral de fines del siglo XIX, y parece responder en principio a una filiación naturalista. La enfermedad, como la "herencia", como el "mal hereditario", fueron temas obsesivos de la ficción experimental: sería ingenuo pensar que la crítica de aquella época hubiera podido excusarse de apelar a esos mismos temas e imágenes para la descripción del declive cultural. Lo "enfermo", entonces, surge como un terreno metafórico de contornos imprecisos, un nodo temático que se irradia a distintos campos e imágenes, y que no deja indemne a la jerga de la crítica. En cuanto al tema de la actuación, por ejemplo, el análisis clariniano deberá apelar a la imaginería de la decadencia para describir la crisis teatral española, y justamente será el problema de la transparencia en la representación lo que divida aguas entre los actores "naturales" y aquellos otros que solo proyectan el síntoma como pura afectación.

Lo explica bien López Quintáns cuando señala que Clarín era prolífico en sus condenas a los actores mediocres, y que la raíz común de sus quejas 
estaba siempre en la necesidad de que el intérprete huyera de la afectación. Pero lo curioso de la observación clariniana sobre el plano de lo actoral no solo tiene reminiscencias de la metafórica naturalista relativa a la enfermedad (el peligro de aquello que no es vital, que es "afectado" por la manera), sino que también replica el modelo trágico de lo agónico: la actuación española está en declive, dice Alas una y otra vez; los grandes actores permanecen como expresiones aisladas que no conforman escuela. El arte dramático perece ante la pasividad conformista de una crítica ignorante. La función de la crítica de teatro, según Alas -y acorde a las exigencias de una praxis en la que suele resonar la semántica de la enfermedad-, es nada más ni nada menos que la del control. Afirma en 1893 sobre sus paliques y opiniones diarias: "Son crítica higiénica y de policía, son crítica aplicada a una realidad histórica que se quiere mejorar, conducir por buen camino" (Alas, Solos 756). Alas sugiere que en España la crítica no puede darse el lujo de comentar solo lo bueno, ya que lo malo se expande con la velocidad asfixiante de un incendio.

La crítica, entonces, debe jugar un rol de riguroso control sanitario, y desde esa certeza moral se desarrolla no solo en el plano de lo textual, sino también de las disciplinas performáticas que constituyen lo teatral junto con la obra literaria. Clarín integra en su libro Sermón perdido, de 1885, el artículo titulado "Los actores". Allí, siempre irónico al demostrar su escándalo, denuncia la carencia de buenas actrices y la adjudica en parte a la rápida complacencia de la crítica: "El representar bien", señala, "no es una dignidad, ni cosa de gananciales que se reparta por mitad entre los esposos. Esto es lo que no quieren comprender varios excelentes actores y señoras respectivas" (Alas, Sermón 177-178). Como el asunto no puede solucionarse con decretos, el irónico Clarín alude a que reina la creencia "epidémica" de que "el mal no tiene remedio". Afirma: "Comprendiéndolo así la crítica desapasionada, se consuela imaginándose que las actrices malas son buenas y las medianas excelentes" (179). Y añade: "¿Tiene esto cura? Acaso no; pero al menos ya que no podamos evitar esta lamentable decadencia, no ayudemos a que caiga de golpe y porrazo el teatro español" (180). Su artículo aparece de ese modo como anticipo vacunatorio ante el aluvión del calendario teatral: "Todo esto viene a cuento porque va a empezar la época de los estrenos, de las batallas... Yo creo que llamando las cosas por su nombre es como puede la crítica trabajar en pro del arte" (183). Para Clarín, el deber previsor del crítico está en "consagrar especial atención y un saludable rigor a los actores que suelen tener gran parte de las culpas que pagan los poetas" (183-184). $\mathrm{Y}$ entre esas culpas, la peor es la del "intolerable amaneramiento" (181), 
producto muchas veces del defecto de la actriz al imitarse a sí misma en gestos aplaudidos prematuramente por la crítica dada al elogio. Resulta claro que son estas imágenes reiteradas las que sustentan en su acumulación la semántica clariniana en torno a lo teatral, a su enfermedad y su cura, al vacío doloroso de la naturalidad y a la responsabilidad moral de la crítica. Casi como si la dinámica ibseniana de la herencia culpógena, enfermiza, se actualizara en la dialéctica española entre la crítica y la escena: si en Espectros, el autor noruego sentenciaba que "los pecados de los padres caen sobre los hijos", en la perspectiva clariniana de la escena, las culpas de la crítica caen sobre la actuación.

Alas bien conocía está lógica de la herencia enfermiza y el estigma moral. No por nada había incluido en su libro Ensayos y revistas. 1888-1892, un artículo sobre Ibsen y Daudet donde denostaba al autor francés por su utilización de la enfermedad como elemento extra-escénico y ponderaba la inteligencia ibseniana para utilizar la fatalidad fisiológica en la acción misma. Mientras en Espectros, Ibsen pone directamente en acción la intensidad desatada del mal heredado, Daudet tematiza en El obstáculo solo el miedo aséptico a heredar el mal. Es, según Clarín, la misma distancia que existe "de lo vivo a lo pintado". Tan viva es la representación del dolor enfermo en Ibsen que Leopoldo Alas teme por su propia vida de lector y llega a decir sobre el final de Espectros: "La simple lectura de tales pasajes da espanto, causa vértigos, aprensiones del contagio del mal" (Alas, Ensayos 426). Tan viva es la representación de la enfermedad que pareciera poder contagiar al que lee. ¿Qué alcance podría tener entonces un material así encarnado en cuerpos de actores no afectados, es decir, de actores vivos? Y algo más, ¿qué características deberían tener esos actores "vivos" para potenciar de manera efectiva la modulación literaria del dolor? Modelos esporádicos capaces de poner en jaque la relevancia "médica" del crítico serán para Leopoldo Alas, Sarah Bernhardt, María Guerrero y -por último, pero inicial en la cronología- Rafael Calvo.

Varias veces escribió Clarín sobre Sarah Bernhardt, y casi siempre valoró en su arte la naturalidad en el decir. Me detengo ahora especialmente en otro de sus ensayos de Sermón perdido titulado "Los Pirineos del arte", porque es donde arremete Alas una vez más contra la crítica de espectáculos que elige el desempeño de la actriz para actualizar la contienda histórica con Francia. Dice allí con extrema ironía: "Aquí no hemos olvidado todavía la invasión napoleónica...; pero ¡ay!, el pueblo de Numancia y de Sagunto (bis) ha defendido enérgicamente su independencia" (Alas, Sermón 228). Alas festeja 
con sorna el silencio "nacionalista" de los críticos ante la presentación de la actriz. Bernhardt es víctima, según Clarín, de la actualización crítica que parece heredar España por entonces como un mal recurrente y que tan bien pudo definir Pozuelo Yvancos al tratar la dicotomía decimonónica entre lo genuino/popular y lo culto/foráneo en el canon teatral de la nación. La cultura elevada y foránea -y más aún si es francesa-implica un "contagio" potencial. Dice Alas, burlón: "Verdad es que los apasionados de la célebre actriz le consagraron el aplauso más entusiástico... ¡Pero esos son los afrancesados! La colonia de los naturalistas, los enemigos del arte nacional" (Alas, Sermón 228). Nuevamente el mal de la crítica pesa sobre la actuación: las culpas de la mirada caen sobre la intérprete. Se lamenta el autor de que no analicen seriamente "la declamación y la mímica de la cómica" y que se detengan en cambio en los rumores de la crónica escandalosa parisina. Sin embargo, algo consuela a Clarín, un gesto último de Bernhardt antes de abandonar la escena. Describe: "Sarah dijo al pasar entre la multitud que aplaudía, algo que entendieron todos; no fue un sonido articulado...; yo creo que fue una resonancia que el aplauso nuestro tuvo en el corazón de Sarah" (233). La imagen del corazón de Sarah Bernhardt en esa lucha cuerpo a cuerpo entre la actuación y los estigmas insanos de la crítica no parece inocente: en el trayecto de lo vivo a lo pintado, el corazón del actor se postula como el punto de partida, siempre en complemento necesario con la razón.

El par dialéctico corazón / cabeza constituye entonces el rasgo fundamental del modelo deseable para la actuación. Richmond ha destacado en el vínculo de nuestro autor con el teatro una dualidad básica que se observa en varios de sus relatos y que "refleja de un lado el entusiasmo teatral del Alas juvenil, quien hasta había soñado con ser actor, $\mathrm{y}$, del otro, el interés intelectual por el género que caracterizaba al crítico Clarín" (66). Subrayo entonces este carácter complementario que Richmond ve en dos etapas de la vida del crítico y que pueden pensarse también como un par constante que Alas deseaba para la verdadera crítica y por extensión para la efectividad actoral que pretendía. "Corazón y cabeza", señala Richmond, "dos modos diferentes de acercarse a la representación teatral que caracterizan, además, dos épocas diferentes en la vida de Leopoldo Alas" (66). Y llamo la atención especialmente sobre estos dos elementos que Clarín parece estrechar en torno a lo teatral, sobre todo porque ya Foucault supo enlazarlos de manera lúcida con la cuestión de la autoridad política del médico -análogo al rol del crítico, en la perspectiva de Alas-. Desde ciertos textos medievales, el papel del médico estaba destinado a un futuro simple de consejero: de lograrse alguna vez cierta eficacia 
política de concordia, el médico - cita Foucault a Lanthenas- solo debiera en los tiempos venideros "dar al legislador y al ciudadano consejos para el equilibrio del corazón y del cuerpo" (Foucault 61). Es desde este ángulo que la opinión clariniana en torno a la praxis dramática y a sus antecedentes parece consolidarse como una especie de consejo autorizado, profesional, armónico y objetivo.

En su ensayo sobre La enfermedad y sus metáforas, Sontag es determinante cuando explica con una precisión admirable que las metáforas patológicas "sirven para juzgar a la sociedad, ya no por su desequilibrio sino por su represividad. Aparecen una y otra vez en la retórica romántica, que contrapone el corazón a la cabeza, la espontaneidad a la razón, lo natural a lo artificial..." (74). Si lo romántico gustaba de contrastar corazón y cabeza, el realismo clariniano y su vertiente crítica teatral apostará por un ideal de actuación renovado, superador, capaz de exigir ya no un contraste entre ambos polos sino un complemento.

María Guerrero, en este sentido, será el símbolo de esa totalidad, la sumatoria de un corazón palpitante y de una cabeza lúcida. Guastavino ha publicado la interesante correspondencia que Clarín mantuvo con la actriz a raíz del estreno de su única pieza teatral escenificada, Teresa, a manos de la compañía de Guerrero. Allí aparecen datos que no hacen más que pulsar la resonancia de las imágenes "patógenas" en el encuadre teatral de Alas. Antes que nada, su circunstancia biográfica: su imposibilidad de ver ensayos y casi de no asistir a la primera función debido a una enfermedad de sus hijos. El 30 de diciembre de 1894 le informa que él mismo está convaleciente y que no podrá viajar a Madrid en enero. El 27 de enero siguiente se preocupa por el estado de la pequeña que actúa en la pieza en el rol de Palmira. Algo le ha afectado el sistema respiratorio: “¿Y la niña?”, pregunta Clarín, "Pobrecilla desconocida Palmira. Dios le cure el pulmón, aunque a mí me den una pateadura" (149). El sacrificio simbólico del drama, cuyo estreno peligra por la recaída de la niña actriz me permite retornar al temor por el "contagio" real ante la vívida escena final de Espectros. ¿Qué implicancias pueden tener verdaderamente los asuntos sanitarios de lo real y las representaciones teatrales del dolor? Aparentemente ninguna, pero en el discurso clariniano en torno a la escena se cruzan con asiduidad, se atraviesan. Estará incluso por estrenarse Teresa y su autor aún dudará de poder presenciar la función: "he tenido a mis tres hijos enfermos y aún están en cama, y muy débiles, y cuanto más tiempo esté con ellos, mejor. Si hubiera tenido que ir hace dos días no hubiera ido por no dejarlos..." (150). Los niños enferman (dentro y 
fuera de escena, dentro y fuera de la ficción) y el autor se ausenta sin poder "iluminar" la actuación de su protagonista. Alas se desespera y trata de guiar a Guerrero por medio de sus epístolas: le detalla por escrito cómo debe interpretar el final de la obra, cuando su protagonista renuncia con heroica resignación al ofrecimiento del señorito Fernando para huir de su matrimonio con Roque, el minero alcohólico. Le dice que las sentencias de Teresa no pueden verse como prédica, sino como dictados de su dolor, y describe: "Esa clase de sabiduría sentimental bien la puede tener una mujer buena, cristiana que padece y aguanta. Ya Vd. me entiende. Vd. salvará este escollo" (150). María Guerrero, en este sentido, aparece como dueña de la totalidad deseable para la actriz modélica: cabeza y corazón comprometidos a la vez en una paradojal sabiduría sentimental que el personaje requiere y que solo siendo "buena", conociendo el padecimiento del dolor sin afectaciones, puede una actriz expresar. La puesta de Teresa, sin embargo, fracasará y algo de todo lo "patológico" del desencuentro previo entre el autor y la escena pudo ser visto por sus creadores como causa del fracaso, de la caída.

Muchos críticos veían en María Guerrero cierta técnica modernizadora caracterizada, según Yxart, por "la eterna y sana tradición de una dicción natural, matizada, detallada y exquisita" (Ezama Gil 265). Pero en esos rasgos veían a la actriz justamente como antagonista de la vieja declamación lírica que signara a intérpretes como Rafael Calvo. Clarín, por su parte, lejos estaba de ver como polos distantes a ambos actores. En su folleto Rafael Calvo y el teatro español, de 1890, Alas desarrolla una serie de reflexiones sobre el estilo de actuación del fallecido intérprete y a través suyo describe una serie de ejes sobre el teatro hispánico, su herencia y su declive. Richmond ve en este folleto "un momento axial, tanto en el desarrollo de la crítica teatral de Clarín como en el de sus propias pretensiones creadoras en este campo" (59). Y queda claro allí que no eran antagónicas para Clarín la sabiduría sentimental de María Guerrero y la fuerza vitalista de Calvo: por el contrario, ambas congeniaban en una imagen integral del actor que servía a Alas como analogía también para la figura deseable del crítico, "porque tal como el crítico-artista funda su labor sobre la obra ajena, y el instrumentista lo mismo, así el cómicoartista (y hay muy pocos) realiza ... la figura ideada e ideal del dramaturgo" $\left(\right.$ Alas Rafael) ${ }^{1}$. El actor, como el crítico, está llamado por el ideal de Clarín a

1 Se sigue versión electrónica disponible, detallada en la bibliografía, que no cuenta con paginación pero sí con herramientas de búsqueda dentro de la web. 
realizar la vida, a construir y encarnar por medio de una amalgama de corazón y cabeza una trama de lo humano que la literatura le provee.

Clarín recuerda su propia juventud y cómo en su llegada a Madrid extrañaba a la madre lejana. En esa ausencia, Calvo fue un paliativo para el dolor de Alas. Exclama el crítico: "¡Dios le pague a Rafael Calvo aquellos momentos en que su voz fue para mí como un regazo!” (Alas, Rafael). Un regazo, dice, y el actor Rafael Calvo se torna rápidamente en "madre". La escena parece actualizar de manera involuntaria ese estigma naturalista que Clarín proyecta siempre en la actuación, la cual aparece una y otra vez como presa fácil de cierta ley ibseniana: aquella que dicta que los hijos heredan los dolores de los padres y que en la actuación palpita la herencia literaria. Y en cuanto a esa herencia, a ese palpitante legado ancestral que condensa para España la literatura áurea, el Rafael Calvo de Clarín tendría mucho para simbolizar.

\section{METÁFORAS DE LA CRÍTICA CLARINIANA ENTRE EL LEGADO ÁUREO Y LA MODERNIZACIÓN DRAMÁTICA}

En pleno franquismo, 26 de enero de 1956, Melchor Fernández Almagro publicó en el diario $A B C$ una nota sobre la familia teatral que había contado entre sus miembros a destacados actores durante varias generaciones sucesivas. Se trataba justamente de una reseña sobre José Calvo, Rafael Calvo y Ricardo Calvo. Del segundo -a quien se aludía como el "incomparable y malogrado Rafael"- se decía que

...enriqueció la herencia paterna de amor a su arte, de elegancia y fausto, de maestría declamatoria, con acentuadísima sensibilidad para percibir y expresar lo poético y lo lírico, apasionada y gallardamente, a tono con el héroe romántico -en el teatro como en la vida- típico de los días que le tocó vivir: los del corazón del siglo XIX, de 1842 a $1888 .(A B C, 26 / 01 / 1956)$

Y acto seguido añadía que

...si los autores dramáticos del Siglo de Oro todavía se representaban con éxito e interés, pese a las mudanzas de los tiempos, se debía en gran parte a Rafael Calvo, fiel al difícil culto de la poesía dramática, sin dejar que se abatiera sobre su repertorio, en momento alguno, el grácil y firme airón del verso castellano $(A B C, 26 / 01 / 1956)$. 
Fernández Almagro recuerda que Clarín dedicó uno de sus más importantes folletos literarios a la figura del actor y destaca lo que ya mencioné: que según Alas la voz del intérprete fue un consuelo ante la lejanía de la familia. Pero lo que más le interesa al crítico de $A B C$ es fundar cierta continuidad con el presente y culminar la nota señalando que el Ricardo Calvo de su tiempo es hijo de aquel Rafael y que como tal permanece "siempre en la memoria de muchos públicos, heredero y conservador de la áurea llave del almario que guarda las almas de Segismundo y Don Juan" $(A B C, 26 / 01 / 1956)$. A primera vista podría pensarse que esa "continuidad" tan preocupada por la herencia y el sostenimiento de la tradición áurea resulta específica del nacionalismo de derechas y más en su período de consolidación simbólica durante los 50 . El mismo Fernández Almagro había publicado en un número de Legiones y falanges de 1941:

El teatro español actual no ha asumido aún la iniciativa que, indiscutiblemente, le corresponde en esta hora trascendental de revoluciones nacionales y renovación universal..., anda todavía un poco indeciso, harto apegado a fórmulas viejas; tan viejas que ya lo eran cuando España se levantó, ansiosa de renacer, contra el republicano-marxismo (cit. en Rodríguez Puértolas 624).

Si el teatro contemporáneo de inicios del siglo XX no podía cumplir con la "hora trascendental" era sin duda porque renovaba una deuda que la actuación, en casos como los de Calvo, había saldado por una especie de continuidad hereditaria. Mientras la escena moderna no compensara el esfuerzo identitario del nacionalismo franquista, la tradición áurea seguiría siendo el cantón central para extraer materiales acordes con sus ideales. Y sin embargo, esto que la propia cultura conservadora de mediados del siglo XX legitimó en la centralidad que Lope había conseguido dentro del canon pelayano, no puede circunscribirse tan solo a un origen anti-liberal. Muy por el contrario, el ensayo Rafael Calvo y el teatro español no solo es una pieza única de su apreciación crítica sobre el teatro del Siglo de Oro, sino que además actualiza ya entonces, y desde su supuesta óptica progresista, la contienda metafórica entre pasado literario y renovación dramática dentro de las complejas lógicas naturalistas que se basan en las imágenes de la herencia y de la enfermedad. En este sentido, incluso puede encuadrarse paradójicamente dentro de la aseveración que Jorge Luis Marzo ha hecho con respecto a la revaloración del barroco en los escritores finiseculares del XIX: para todos estos intelectuales, la tradición española se encuentra en aquel arte "que no se deja contaminar 
por herencias culturales ajenas (aunque pueda compararse a ellas) ni por compromisos artísticos que desvíen al artista de su enorme responsabilidad como "demiurgo" de la nación" (Marzo 235).

Así, explica Clarín en el texto que le dedica a Rafael Calvo que la biblioteca se ha ido tornando tumba del teatro clásico español:

El teatro español... es también una gran idea que se va muriendo en la conciencia del pueblo y en las propias encarnaciones. En el ritmo del verso dramático español antiguo (no en el de este siglo) había un singularísimo encanto;...y el amor, la vanidad, la alegría, la nobleza, el idealismo, iban saltando por el cauce sonoro del romance, la redondilla y la quintilla, la décima y la silva... Pero aquel verso español no se había hecho para dormir prensado en las frías columnas de Rivadeneira, donde es a su verdadera íntima esencia, lo que son las patas de araña del pentagrama a las notas aladas de Rossini (Alas, Rafael).

Clarín exclama que "al verso hay que decirlo, y declamarlo, y representarlo", y que en esa misión "auxiliar" del actor deben trasparentarse todos los primores de lo que interpreta: "el cómico es al poeta, lo que la atmósfera al sol: cuanto más diáfanos, mejores; todo en ellos es asunto de pureza; no tienen más que dejar pasar la luz, la hermosura" (Alas, Rafael). En ese contexto, Rafael Calvo se eleva como un médium infrecuente de las glorias literarias del pasado. De hecho llega a decir que "jamás ha habido en Madrid una compañía de cómicos buenos", pero que en cambio, si no hemos tenido jamás "una compañía que pudiera hacernos ver una comedia de Calderón tal como ella es, hemos tenido algunos, poquísimos, actores y actrices que supieron, unos en un tiempo otros en otro, enseñarnos la verdad de lo que era tal o cual personaje" (Alas, Rafael). Y remata con la conciencia de un símbolo cuyo significado polimorfo va a ocuparme especialmente:

Uno de estos contadísimos cómicos buenos era Rafael Calvo: su mérito superior era hacernos oír la música viva de ese verso castellano de nuestro teatro glorioso. Y Calvo acaba de morir en Cádiz, comido por la viruela. La triste realidad es un terrible poeta realista: Calvo, la última cuerda de la lira del teatro más idealista, más lírico, la voz del idealismo más aéreo... ha muerto como Naná, la heroína de la novela más naturalista. Sí, la realidad aunque realista, es poeta porque hasta tiene sus simbolismos: parece que la viruela, al envenenar la sangre de Calvo, pudrió la sangre de Segismundo, de Mireno, El Vergonzoso 
en Palacio; de Federico, el de El castigo sin venganza; del hábil amante de El desdén con el desdén. ¿Dónde está ahora el artista que en su voz, llena de fiebre, vibrada, algo rimbombante, enfática en la pasión, pero armónica, intensamente expresiva del ritmo interior de la idea, tenía un símbolo de las inefables bellezas de nuestra inspiración dramática de los siglos de oro? Está en el sepulcro y en el recuerdo impotente de sus admiradores... (Alas, Rafael).

La imagen es de un simbolismo elocuente: el cuerpo de Calvo, donde había logrado sobrevivir la tradición teatral áurea, es arrasado por la enfermedad prototípica de la ficción naturalista. Lo paradojal es justamente esa construcción de lector que hace Clarín ante la muerte del actor, donde explica el símbolo del agónico fin del legado áureo sin poder escapar de la articulación crítica del campo metafórico de la enfermedad y de la aparición recurrente de esas imágenes patógenas tan propias del naturalismo ficcional. En el análisis que Alas propone sobre la patología simbólica del intérprete fallecido estalla una vez más el campo de lo enfermizo y hasta de lo fétido, abriendo al menos dos direcciones que parecen iluminar ciertos ejes críticos muy presentes en la recepción clariniana del legado teatral del Siglo de Oro. En primer lugar, me refiero al vector que señala una tensión compleja entre la tradición heredada

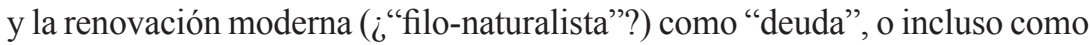
"enfermedad"; y en segundo lugar, aludo al tema del barroco como estigma de actualización transtemporal y polimorfa, como un nodo que tampoco desconoce a la "viruela" como imagen de sus culpas.

Empiezo entonces por el primer eje, el cual vincula al pasado literario con la caída típicamente naturalista del cuerpo "tomado" por la enfermedad. En su folleto de 1890, Clarín enuncia con evidente melancolía que Calvo

...está en el sepulcro, y con él desvanecidas en larvas de la memoria las encarnaciones plásticas de aquellos seres extranaturales en lo accidental, puramente humanos en el fondo del alma, que sirvieron a nuestros grandes poetas dramáticos para transparentar uno de los más bellos, más fuertes, más luminosos ideales que brotaron en la gran primavera humana que se llamó Renacimiento (Alas, Rafael).

Si la realidad es un poeta realista, me atrevo a arriesgar que Alas está muy cerca de lo real. La putrefacción del cuerpo de Calvo -las "larvas"- trascienden la carne y "desvanecen" incluso las criaturas ficcionales que constituyen el territorio del drama barroco. Calvo es Naná, curiosa y paradojalmente, pero no tanto. Porque como en la heroína de la novela -y esto es lo que Alas pasa 
por alto de manera tal vez inconsciente, tal vez intencionada- organiza con su trágica muerte el destino trunco de algo que la excede por mucho: del Imperio, del sueño imperial en riesgo de un Napoleón III asediado por las fuerzas republicanas. Calvo es Naná no solo por la coincidencia del mal que los condena a ambos a la muerte, de un lado y del otro de la ficción - con esa facilidad clariniana para percibir de modo fluido la circulación de enfermedades entre lo real y lo que no lo es-. Calvo es Naná porque en su cuerpo "traslúcido" supo interpretar el tesoro literario del pasado imperial sobre el que se abate ahora un sinfín de calamidades. Calvo muere y en el interior de su cuerpo muere la literatura dramática del Imperio: la música del teatro áureo calla en el silencio del actor moribundo y además en el final de un siglo donde languidece el dominio colonial. Y en ese sentido no solo se trataba del mejor intérprete por su eficacia técnica, sino también por haberse vuelto él mismo parte del legado áureo. Tal como explica Alas, "a fuerza de cantar el modo calderoniano", Calvo había llegado a ser como esos instrumentos de músicos célebres, los cuales "porque han estado largo tiempo en manos de los grandes maestros, guardan algo de ellos para siempre" (Alas, Rafael).

Clarín evoca la muerte de Calvo y en su silencio registra el callamiento de la más emblemática tradición teatral áurea, aquella que fue símbolo del Imperio cuyo declive llegará hasta el fin del siglo XIX. También Naná muere y su silencio contrasta con el griterío que afuera persiste y que denota el declive imperial. El cuerpo de Calvo, carcomido por la viruela, es el último reducto vital del teatro del Siglo de Oro: se trata de un símbolo que trasciende la casualidad y Alas lo afirma más avanzado el folleto. Se trata de una "deuda" con el pasado, de una "herencia" controversial al mejor estilo ibseniano: "me atrevo a sostener", dice, "que el siglo XIX no ha dado a España un renacimiento dramático que podamos ofrecer al estudio y a la admiración de los extranjeros, como descendiente legítimo del gran teatro que es admirado en todos los países de alguna cultura estética" (Alas, Rafael)². Clarín se burla

2 Casualmente, ya en su escrito de 1881, "El naturalismo en el teatro", Zola había generalizado la misma cuestión al subrayar el desfase genérico de la modernidad: "El espíritu del siglo XIX, con su retorno a la naturaleza, con su necesidad de investigación exacta, iba a abandonar la escena, en la que le molestaban demasiados convencionalismos, para afirmarse en la novela (...). Si el siglo XVII fue el siglo del teatro, el siglo XIX será el siglo de la novela" (Zola, 2002: 181-182). Y aunque augure que el teatro futuro será naturalista o no será, sus especulaciones para la "fórmula" de ese teatro acarrean un estigma retrospectivo del cual Alas también sería víctima. De hecho, la única estrategia inmediata que Zola encuentra para 
de aquellos que como Cañete conciben y recuerdan el romanticismo teatral español -y el moderado realismo que le siguió- como "un florecimiento de la escena de Lope y de Calderón”... Y agrega que la comparación de lo que ven con lo que recuerdan "debe de ser contraste de efecto apocalíptico, de danza de la muerte. Esto, ya más que la podredumbre, debe de figurárseles la orgía de gusanos que han devorado el cadáver del teatro español" (Alas, Rafael). El teatro decimonónico español -y más aún el finisecular- no hereda según Alas la genialidad de su predecesor áureo. Juzga absurdo el desesperado intento de la crítica de parangonar el declive del drama español con las glorias del imperio cultural: parece reírse amargamente de que se compare a Rubí o a Eguílaz con Lope de Vega o Calderón. Y concluye, como si la idea en su máxima generalidad pudiera extraerse claramente del cuerpo devastado de Calvo:

...lo que yo quiero decir es que el estudio imparcial, sereno y reflexivo, y hecho con atención asidua al buen gusto y al sentido común, no me permite reconocer en el teatro español del siglo XIX una gran obra colectiva, un renacimiento nacional de literatura dramática, en que poetas, críticos, público y ambiente social concurran a dar al espíritu español el tinte especial que le señala con esa particular tendencia del genio patrio en el siglo XVII... (Alas, Rafael).

Como Fernández Almagro años después, pareciera que una de las pocas certezas en la actualización de esa continuidad con el teatro genuino y nacional debía buscarse en el actor Rafael Calvo: no en la literatura dramática de su tiempo solo sacudida por "chispazos" azarosos de belleza dramática (El Trovador, Don Álvaro, Don Juan), ni tampoco en esos "caciques de escenario" que, tal como dice Clarín, "llegaban a la monotonía, a la exageración y al amaneramiento, infestaban con esta peste a todos los cómicos de su compañía, y de esperanzas de un verdadero teatro nacional, se convertían en focos de infección" (Alas, 2000). Puede haber algo bueno en lo que se escribe, sospecha Clarín, pero "el olor del potaje predomina, y da náuseas y tristeza al estómago" (Alas, Rafael).

la modernización del drama es volver al pasado con las herramientas científicas del presente: "En una palabra", dice, "la fórmula clásica me parece buena con la condición de que se utilice el método científico para estudiar la sociedad actual, como la química estudia los cuerpos y sus propiedades" (186). 
A través de Calvo y de su muerte, el crítico Clarín -quien curiosamente se resistiera a la ortodoxia naturalista- consigue reponer las características del declive dramático español solo a través de enmarcarlo en unas coordenadas extremas del naturalismo más clásico. Calvo es Naná también por la "viruela", por la referencia inexcusable de una enfermedad que a través de la novela de Zola se torna nodo simbólico del naturalismo: de la estética renovadora, experimentalista y moderna del naturalismo. La viruela no es un elemento accidental en Naná: Zola la utiliza para uno de los remates más encarnizados de la novelística del siglo XIX. La viruela es el arma secreta que le sirve para asestar su golpe final a una protagonista cuya fatalidad, ante todo, refuerza la idea de un destino moral capaz de cobrarse las deudas de cualquier exceso materialista, de la lascivia y del puro interés.

Consciente del pulso de su obra, y como si se tratara del último movimiento de una sinfonía, Zola parece acudir a un ritmo final que resulta contrastante con la detenida introducción de su novela. El vocerío final del relato, que convoca a marchar hacia Berlín, determina el estrépito de los últimos sucesos de la fábula: el tempo se acelera y la narración comienza a saldar deudas informativas que tienen por objetivo robustecer la trama necesaria para sostener la moralidad de la conclusión. Naná yace en un hotel pagado por su némesis, la actriz Rosa Mignon, quien tal vez por un miedo reflejo es la única que accede a cuidarla en su estadio terminal. El lector desconoce los orígenes de este abrupto asalto de la enfermedad y la exigencia naturalista de la historia rápidamente compensa esa falta. Luego de su última excentricidad -la más literal quizás-, Naná ha vuelto de una pródiga estancia en Rusia. En viaje a lo que sería su última visita, Lucy narra a otras de las antiguas compañeras de Naná, el modo en que contrajo el mal. Una vez más, la herencia como tema encarna en la peripecia, y es literalmente el hijo, ese hijo pequeño, siempre abandonado, siempre ausente y frágil, el que la condena. Si la realidad es un gran escritor realista, la ficción usa el destino como cobrador de deudas. Explica el personaje de Zola:

Naná llega de Rusia, no sé por qué, tal vez una disputa con su príncipe... ¡Bueno!, cae sobre su pequeño, que tenía la viruela; el pequeño muere al día siguiente, y ella se agarra con la tía a propósito del dinero que debía enviarle y del que la otra nunca ha visto un céntimo... Parece que el niño murió de eso; un niño abandonado y mal cuidado... ¡Muy bien! Naná se larga ya a un hotel y después tropieza con Mignon... De improviso se siente indispuesta, tiene 
escalofríos, náuseas, y Mignon la conduce a su casa, prometiéndole velar sus asuntos... (Zola, Naná 1011).

La fatalidad se conjura contra los errores del pasado y la ley de Ibsen se cumple también acá pero con la significativa inversión del contagio. Como ocurrirá en Espectros, la culpa de los padres cae sobre los hijos, pero es el hijo quien condena a su madre a través del contacto. La viruela es el estigma paradojal de una moralidad dañada que se cobra sus lesiones en el cuerpo inocente del hijo de Naná. Las compañeras de Naná quieren "ver" (sus viejos amantes, por el contrario, prefieren la distancia): Lucy dice que una vez enterada, "inmediatamente he querido ver" (1011); una vez fallecida, y mientras en la caldeada alcoba velan entre todas su cama rodeada de cortinas, el narrador menciona que "cierta necesidad de ver las tenía clavadas sobre la alfombra". Cualquier lector del texto podrá recordar la aparición primera del personaje sobre un escenario: "desnuda, sí, con una tranquila audacia, segura de la omnipotencia de su carne" (565). Queda lejos el inicio donde se decía que su cara sonreía, pero "con una sonrisa devorahombres" (565). La ansiedad apunta a acicatear el deseo esperable del lector de "ver" él mismo la devastación de ese rostro. Pero nada augura la bestial revancha simbólica que el narrador manipula sobre el destino moral y el rostro cadavérico de Naná cuando describe:

Era un osario, un montón de humores y de sangre, una paletada de carne putrefacta, arrojada allí sobre un colchón. Las pústulas habían invadido toda la cara, tocándose unas a otras; y marchitas, hundidas, con su agrisado aspecto de lodo, parecían ya un enmohecimiento de la tierra sobre aquella papilla informe, donde ya no existían rasgos... Y sobre aquella máscara horrible y grotesca de la nada, los cabellos, los hermosos cabellos, conservando sus reflejos de sol, corrían como chorros de oro. Venus se descomponía. Parecía que el virus recogido por ella en el arroyo de las calles, sobre las carroñas toleradas, ese fermento con que había emponzoñado a un pueblo, acababa de subírsele al rostro y lo había podrido (1027).

Se trata de la putrefacción patógena del rostro, de la consecuencia de una obra que según el propio narrador era comparable a la de la mosca, la cual "escapada de la basura de los arrabales, llevando el fermento de las podredumbres sociales, había envenenado a aquellos hombres sólo con posarse sobre ellos" (1008). La cara devastada de la pestífera Naná: esa es la imagen que el crítico Clarín elige como analogía del rostro de Calvo, terreno arrasado por la misma 
"viruela" simbólica, eco ahora también de la puja entre la decadencia del drama moderno y la herencia del teatro áureo. Cabe preguntarse, ¿por qué? ¿Cuáles son las implicancias de esa comparación, más allá de una filtración epocal que contagiaba a la crítica de imágenes recurrentes en la ficción naturalista? ¿Qué otro sentido produce ya no ligado al eje declinante de lo imperial? $\mathrm{Me}$ atrevo a afirmar que Clarín encuentra en las propias estrategias retóricas de ese naturalismo con el que mantenía un controversial vínculo, el atajo más directo para escenificar su idea ambigua sobre el conflicto entre el pasado literario español y sus necesidades de renovación. En la superposición de los rostros de Naná y de Rafael Calvo, el crítico Clarín halla la metáfora más directa y menos lesiva de su opinión bifronte sobre el canon del Siglo de Oro: la añoranza nostálgica de ese esplendor teatral y el implacable acecho de una renovación moderna que no pasa muchas veces de ser forma excedida, deformación manierista y sin sentido: es decir, "afectación" sin más.

\section{LA OTRA CARA DE LA CONTIENDA: PARDO BAZÁN Y EL CAMINO DE ZOLA A LOMBROSO}

La novela de Zola, entonces, no solo debió instalarse por su contundencia, sino también porque la capacidad del personaje para constituirse rápidamente en el símbolo mismo de la radicalidad técnica del naturalismo era compartida en España por muchos lectores competentes. Pienso por ejemplo en un caso que resulta central para mi tratamiento: las lecturas al respecto de Emilia Pardo Bazán. Sus artículos periódicos de 1882 aparecidos en La Época bajo el título de La cuestión palpitante desglosan muchas de las problemáticas sobre Zola y la escuela naturalista que el propio Clarín -quien prologara luego el libro homónimo- retomaría numerosas veces en los años posteriores y con resonancias que llegarían incluso a su folleto crítico sobre Rafael Calvo y el teatro español. En el prólogo a la obra de Pardo Bazán, Alas valora la escuela naturalista y lamenta que en España "las ideas nuevas suelen comenzar a

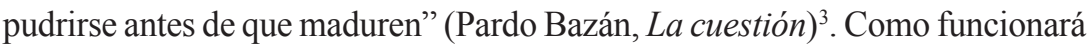
con el correr de los años en la superficie del rostro de Naná o de Calvo, el naturalismo inmaduro, precoz y malentendido será para Clarín "putrefacción"

3 Se sigue versión electrónica disponible, detallada en la bibliografía, que no cuenta con paginación pero sí con herramientas de búsqueda dentro de la web. 
inminente. Intenta definir al movimiento por la negación, con una lógica cercana al método clínico del descarte de síntomas. Así, el naturalismo, para Alas, no es el mero regodeo de la descripción de lo vil, ni es análogo al positivismo, ni tampoco es pesimismo puro o una receta para la escritura de novelas. Pero por sobre todo y antes de elogiar a la autora del libro que prologa, Clarín deja en claro que el naturalismo "no es la imitación de lo que repugna a los sentidos" (Pardo Bazán, La cuestión). Y desconociendo sus propias licencias -recordemos en su artículo "Ibsen y Daudet" el miedo al "contagio" que le provoca el vívido final de Espectros-, trata de fijar una distancia prudencial entre la realidad y la fetidez de la ficción:

...la literatura no puede consistir en tales sensaciones ni en su imitación siquiera. Las sensaciones no se pueden imitar sino por medio de sensaciones del mismo orden. Por eso la literatura ha podido describir la peste de Milán y los apuros de Sancho en la escena de los batanes, sin temor al contagio ni a los malos olores" (Pardo Bazán, La cuestión).

Como puede notarse, esta es una demostración más de cómo Alas oscila con respecto a la porosidad entre ficción y realidad en torno al eje naturalista de la enfermedad. Sin embargo, la imbricación de esa metáfora en una época de crítica literaria "higiénica" como la que reivindicaba Clarín era común incluso en Pardo Bazán. Justamente a propósito de las relaciones entre naturalismo y moral, la autora de La cuestión palpitante menciona también a Naná y sostiene que es un error ver como único género de inmoralidad suya a la erótica. Opina que hay novelas que por su carácter antisocial o antirreligioso son más "peligrosas" que la de Zola. Pardo Bazán alude con lucidez a la confusión que los censores tienen al homologar lo inmoral con lo grosero. El dramaturgo Dumas hijo, en este sentido, le parece más peligroso que Zola debido a que sus libros apelan a una didáctica "en serio". "Naná", dice, "es acaso la obra por la cual se juzga con más severidad a Zola. ¿Será debido al asunto? Siento que más bien a la falta de tino, al cinismo brutal con que está tratado" (La cuestión, 1966: 151). Pareciera que Pardo Bazán es la primera en localizar la posibilidad de ver una autorreferencialidad simbólica del naturalismo en la descripción de algunas de sus criaturas y enfermedades. Algo que va a abrir una línea directa con la analogía entre Naná y Calvo que haría su prologuista y a través de la cual situaría la tragedia compleja del legado áureo ante la modernidad.

Pardo Bazán sigue a Valera en la idea de que la literatura nunca fue decorosa e irreprochable, y que como ejemplo primario de ello están 
"nuestros clásicos y el teatro antiguo" (149): "Si los clásicos delinquieron y los románticos también, ¿por qué echar sobre naturalistas y realistas todo el peso de la culpa?" (149). La hija se rebela: en su concepción sui generis del naturalismo, Pardo Bazán se resiste a las acusaciones de inmoralidad que la "enfermedad" estética de los modernos habría propagado en contraste con la salubridad del Siglo de Oro. Es cierto que Zola, según Pardo Bazán, parece preferir el caso patológico al normal, y así y todo, fuera de esa preferencia "atacable", lo reconoce como "grande, eximio, extraordinario artista" (135). Por su defecto solo puede exclamar: "¡A Dios gracias, hay de todo en el mundo y aún en este siglo de tuberculosis y anemia, no falta quien tenga mente sana en cuerpo sano!" (135).

Sin embargo, si bien no falta salud en el mundo de Pardo Bazán, la contundencia simbólica de Naná la intuye ya desde su propia crítica, cuando afirma sin dudas que la estética "impersonal" de Zola es simbólica y que la protagonista de su novela es claramente un símbolo: "Sobre la rubia cabeza de Naná", explica Pardo Bazán, "el autor acumuló toda la inmundicia social, derramó la copa henchida de abominaciones, e hizo de la pervertida griseta un enorme símbolo, una colosal encarnación del vicio" (144). Lo curioso, justamente, es que la efectiva inmersión de ese símbolo en la crítica española de entonces no solo permitió una de las lecturas críticas más interesantes sobre la escuela de Zola, sino que habilitó su propia irradiación simbólica en la explicación crítica de la relación entre la modernización naturalista y el legado tradicional de la literatura nacional. Si Pardo Bazán sugería ver en Naná la encarnación del vicio y Clarín prefería ver en ella el final simbólico de la tradición áurea a manos de una malentendida enfermedad "naturalista", poca distancia queda para percibir el vínculo entre el padecimiento y la tensión hispánica entre pasado y futuro.

En La cuestión palpitante, la autora enfatiza algunos puntos que Clarín intentaba matizar en el prólogo e invita a no juzgar "de oídas" al naturalismo francés (29). Como Clarín con la metáfora de Calvo, Pardo Bazán se posiciona de manera ambigua y sin desmentir los excesos de la "enfermedad" naturalista, asume su responsabilidad "médica" y hasta "curativa":

Aún suponiendo que naturalismo y realismo fuesen un error literario, un síntoma de decadencia, como el culteranismo, v. gr., todavía su conocimiento, su análisis, importaría grandemente a la literatura. ¿No investiga con afán el teólogo la historia de las herejías? ¿No se complace el médico en diagnosticar una enfermedad extraña? (31). 
El campo semántico de la enfermedad y de lo clínico se expande hasta cubrir todo el contorno de la misión crítica:

Cada profesión tiene su heroísmo propio: el anatómico es valiente cuando diseca un cadáver y se expone a picarse con el bisturí y queda inficionado del carbunclo o cosa parecida...; el escritor ha menester resolución para contrarrestar poco o mucho la opinión general; así que probablemente, al emprender este trabajo, añado algunos renglones honrosos a mi modesta hoja de servicios (32).

El crítico como médico, al estar en contacto con su objeto de análisis, puede "contagiarse", pero su responsabilidad lo empuja igualmente al riesgo. Cabe preguntarse aquí si Clarín, con su prólogo al libro de Pardo Bazán, no se expone también al "contagio" de ese nuevo carbunclo que parece venir a desplazar en lo teatral la herencia ineludible de la "viruela" barroca.

Por su parte, Pardo Bazán pide allí, de algún modo, cierta precisión científica que permita extraer de la fatalidad lo que toca al adelanto intrínseco a cualquier crisis. Del ensayo de la autora se desprende un apotegma bastante cercano al concepto médico de "prevención": el temor se compensa con saber. Prueba de esto es su rechazo a que la literatura realista y la naturalista sean conminadas a un plano de inmoralidad que las empuje al "afuera de la ley" (29). Es curioso que el criterio crítico de Pardo Bazán se torne aquí defensivo pero también policial, sobre todo porque años después -en una serie de artículos de 1894- su deriva la llevaría a ocuparse de esos mismos métodos deterministas que con Lombroso ya se habrían alejado de la literatura para intentar poseer entonces una incidencia física en lo real, en el juzgamiento de los seres según su medio y su apariencia, y ya no en la simple especulación ficcional que se desprendiera de las tesis de Zola ${ }^{4}$. De hecho, sus ensayos sobre Lombroso publicados en Los Lunes de El Imparcial llevan el paradójico título de La nueva cuestión palpitante, y parecen ser -más de una década después- la reflexión esperable sobre ese pasaje peligroso que hacen los postulados del

\footnotetext{
Causa cierta sorpresa la significativa paradoja de que ese año de 1894 en que Pardo Bazán publica estas opiniones, también fuera el del estreno de Teresa, la pieza de Alas tan atacada por su "fetidez" moral, tan criticada en los diarios por la presentación de un mundo "crudo", no digno de ser visto ni oído sin espanto ante la "enfermedad" moral que exhibe, ante el carácter desbordado de un trabajador alcohólico y de la miseria a la que su familia se ve sometida por el ruin medio en el que subsiste.
} 
naturalismo literario directamente desde la imaginación al determinismo lombrosiano que intenta dominar el plano real de la ley.

En La nueva cuestión palpitante, entonces, la metáfora de la enfermedad vuelve a hacerse presente no solo como tema sino como elemento de arrastre hacia el pensamiento sobre el pasado literario español. La autora insiste allí en el equívoco de la definición que hace Lombroso de "degeneración”, como

...la acción de la herencia sobre la prole de los individuos dados a la bebida, atacados de sífilis, tisis o demencia, o dañados por grave causa accidental, como el mercurio o las lesiones del cráneo. Estas causas [...] perpetúan en el paciente las neurosis y otras enfermedades y lo que es peor, los agravan en sus descendientes... (Pardo Bazán, La nueva cuestión palpitante III 1).

Y repone la opinión errada del criminólogo italiano con respecto a la genialidad: "Esta degeneración se revela en los individuos por ciertos y determinados caracteres físicos y morales, que según Lombroso se encuentran muy a menudo (los primeros especialmente) en los genios" (1). Me permito opinar que este es el límite 'moral' donde ha llegado la instrumentación de la metáfora patológica naturalista y donde la funcionalidad de la imagen de la enfermedad toca su máxima peligrosidad para la crítica, ya que resuena en el problema del canon. Desde aquella "enfermedad" metafórica del naturalismo invadiendo el rostro de Calvo -el intérprete áureo como remedo de Naná-, los presupuestos de la escuela experimental se han tornado criterios policíacos y han vuelto a sacudir a la crítica con su incidencia violenta en lo extraliterario. Si los genios tienen rasgos físicos propios de la "degeneración", y los descendientes padecen el recrudecimiento de los síntomas, según los dictados de Lombroso que combate con ahínco Pardo Bazán, los herederos del esplendor del Siglo de Oro corren el riesgo de ser degradados al estatuto de "enfermos" que corren con las deudas paternas.

Pardo Bazán se apura a señalar que esas particularidades morales y físicas que según Lombroso vinculan "a los genios y a los locos y a los degenerados", se encuentran también entre el vulgo normal. Y expresa que no comprende cómo un hombre que dice basarse en la observación experimental, extrae conclusiones de fisonomías desaparecidas hace mucho: se pregunta, " ¿es fácil fundar la experimentación en lo pasado?". "Si tan fácil es trabucar los datos relativos al carácter de los que viven, figúrense ustedes de los muertos, y calculen si es aventurado deducir de un hecho suelto, e inexacto quizás, la degeneración o la demencia" (Pardo Bazán, La nueva cuestión palpitante 
III 1). Y en esta línea defensiva de los próceres literarios del pasado contra el método descriptivo determinista, la reseña ataca rápidamente todos los errores de información en los que recae el italiano. Y dice: "Verdad que en todo lo español ni por casualidad da pie con bola Lombroso: desde los nombres -a Lope de Vega le llama López de la Verga...- hasta los hechos más trillados y conocidos" (1).

El 2 de julio de 1894, la escritora arremete contra el italiano una vez más. Su argumentación vuelve a lo que parece ser central: la defensa del canon pretérito y genuinamente español. Acerca del peligroso estigma lombrosiano que gravita sobre los sujetos sin rasgos propios de su país, dice Pardo Bazán:

El no ofrecer el tipo fisionómico más común en su patria, no sé si puede considerarse signo degenerativo... Los rostros de Cervantes, Quevedo, Velázquez, Lope de Vega y Calderón no pueden ser más genuinamente españoles. Por otra parte, la mezcla y diversidad de razas que existe en toda nación europea, explica satisfactoriamente la aparición de tipos que difieren del clásico nacional (Pardo Bazán, La nueva cuestión palpitante IV 1).

Actualización del "contagio" naturalista, Pardo Bazán refuta la teoría de Lombroso, pero al mismo tiempo habla de rostros "genuinamente" españoles. ¿Qué es un rostro "genuinamente" español sino la constitución de una causalidad entre la hispanidad como herencia y a la vez su concreción como estigma? Por otra parte, llama la atención la recurrencia con que menciona a Lope. Párrafos más adelante, de hecho, vuelve a surgir su nombre cuando se burla de la idea lombrosiana de que los artistas crean sus obras maestras en estado de sonambulismo. Explica Pardo Bazán que, muy por el contrario, se trata de trabajos conscientes, y dice: "corrigen, enmiendan, forjan la poesía. Esto sucedía con Víctor Hugo y sucedió a nuestro Lope" (Pardo Bazán, La nueva cuestión palpitante IV 1). Lope de Vega, el autor nacional por antonomasia, el artífice central del canon áureo, es la prueba más sostenida por la autora para el divorcio entre genialidad y demencia. En estos artículos, Pardo Bazán se regocija en destruir la familiaridad que Lombroso ve entre el genio y el salvaje, el loco o el idiota. Deconstruye la idea lombrosiana de que la obra genial es hija de la "epilepsia poética y la alucinación enfermiza" (Pardo Bazán, La nueva cuestión palpitante IV 1). Sin esta defensa, ¿qué sería del pasado literario? ¿Qué quedaría para los sucesores de un Siglo de Oro producto de genialidades lindantes con patológicas locuras? 
El 30 de julio del mismo año, en otro artículo de la serie, Pardo Bazán responde a la pregunta tangencial de cómo deben escribirse las biografías de los hombres ilustres. Contrasta Los genios de Lombroso con Los héroes de Carlyle. Más allá de algunas desavenencias, su punto de vista coincide más con el del sajón -sobre todo en la subestimación moderna de la heroicidad-, y es así que La nueva cuestión palpitante se revela no solo como un ataque a Lombroso sino también como una defensa del genio nacional y del canon que el cientificismo naturalista había querido socavar. En esta línea, la figura de Lope, claro está, vuelve a aparecer. Pardo Bazán se pregunta si hay que falsificar la vida de los notables solo para atraer la atención de la 'turbamulta'. Y responde negativamente, puesto que a pesar del escándalo que provocan "los galanteos y tercerías de Lope de Vega", la muchedumbre no es tan cándida como para dejarse engañar con exageraciones efectistas. Y aludiendo a la responsabilidad "moral" del siglo XIX y de su crítica frente al canon heredado, remata:

Si es verdad que el valor de una época se ha de juzgar por la acogida y agasajo que hace a sus grandes hombres, (...) abatida edad es la nuestra. Sin embargo, debe esperarse que esta crisis sea violenta y corta, cual todas las revoluciones. Restauraremos al genio, y lo restauraremos sin valernos de falsedades ni embustes (Pardo Bazán, La nueva cuestión palpitante VI 1).

Restaurar al genio moderno: he ahí la misión crítica del siglo XIX, según Pardo Bazán, una vez pasadas las “convulsiones" enfermizas del naturalismo dogmático (la cuestión palpitante) y de sus ramificaciones lombrosianas (la "nueva" cuestión palpitante). Sin embargo -y esto es lo curioso y notable si se recuerda la referencia metafórica del "contagio" tanto en Pardo Bazán como en Clarín-, su tratamiento de una estampa de Zola en los antiguos textos críticos de La cuestión palpitante parece tener un parentesco cercano con algunos de los mismos excesos que la autora condenaría en Lombroso años después. Como si el contacto con el objeto analizado y sus derivaciones más peligrosas cumplieran sin demora el designio profetizado por ella misma: inficionarse de los desvíos propios del naturalismo y de sus desprendimientos.

En el capítulo XIII de su análisis de 1882 sobre el naturalismo, la autora de Los Pazos de Ulloa se refiere al retrato de Zola. Dice allí: "Al comparar los retratos de algunos corifeos del romanticismo con el único que de Zola pude procurarme, comprendí, mejor que leyendo un tomo de historia de la 
literatura moderna, cuánta distancia separa Graziella del Assommoir" (127). Y añade:

El pensamiento se graba en la faz, las ideas se filtran, se transparentan bajo el cutis, y los semblantes de la generación romántica descubren aquellos entusiasmos y melancolías, aquel ideal poético y filosófico que caldea sus obras. El largo cabello, las facciones finas, expresivas, el fuego de los ojos, el porte altivo y meditabundo a la vez, son rasgos comunes a la especie... En cuanto a Zola... Su cara es redonda, su cráneo macizo, su nuca poderosa, sus hombros anchos como de cariátide, tiene trigueña la color, roma la nariz, recia la barba y recio y corto también el cabello. Ni en su cuerpo atlético ni en su escrutadora mirada hay aquella distinción, aquel misterioso atractivo, aquella actitud aristocrática, un tanto teatral, que poseyó Chateaubriand en sus buenos tiempos... (127-128).

Como un científico naturalista, como un esteta del naturalismo francés o como un seguidor radical de Lombroso, Pardo Bazán describe a Zola y lo arranca del atractivo "romántico" curiosamente por sus rasgos físicos, capaces de "determinar" -cual medio "metafísico"- el carácter aburguesado de sus obras, si bien meritorias, no heroicas, nada románticas y poco "doradas". "En resumen: el físico de Zola corresponde al prosaísmo, al concepto mesocrático de la vida, que domina en sus obras" (128).

No considero digresivo el itinerario por estas opiniones críticas de Pardo Bazán que, por el contrario, resultan familiares a los juicios de Alas en cuanto al dilema entre tradición y renovación, y en especial a la trampa entre pasado y futuro donde él percibe situado al canon áureo. Tanto en estos trabajos de Pardo Bazán, como en el folleto de Alas sobre Rafael Calvo o en su prólogo a La cuestión palpitante, lo que verdaderamente palpita es una contradicción radiante de significados sobre la tensión entre la tradición literaria nacional y el advenimiento avasallante y foráneo de la experimentación naturalista. Los modos en que esa contradicción se juega pueden verse en la imbricación de los análisis críticos con las propias metáforas de la enfermedad, tan comunes en la ficción naturalista. Sus derivas llegan al extremo de juzgar el error evidente de los estudios lombrosianos como derivaciones excesivas de los procedimientos experimentales del naturalismo literario y, sin embargo, tanto Alas como Pardo Bazán habrían recaído en ese mismo modo de mirar mucho antes de juzgar como nefasta la perspectiva del italiano. De hecho, la metaforización de la contienda entre la modernidad literaria y el legado 
áureo en el rostro arrasado y simbólico de Calvo, en su otrora vigoroso cuerpo caracterizado como natural para la potenciación -y caída- del esplendor pretérito; y la análoga desvalorización de la obra de Zola a partir de los rasgos físicos de su retrato, son procedimientos cercanos al valor significante de la fisonomía en Lombroso, es decir, cercanos al avatar más desmedido del naturalismo literario. Como un virus cuya inoculación desconoce el que lo porta, la trama retórica de la crítica "higiénica" da cuenta en sus hacedores de un "contagio" bastante previo a los concienzudos repasos de aquello que consideraban "síntomas" del mal moderno, tan nuevo como inevitable.

\section{CONCLUSIONES SOBRE LA TORNA MODERNA DEL IMPERIO: LA ENFERMEDAD COMO METÁFORA EN EL ESTIGMA BARROCO}

En el apartado anterior hube de señalar que cualquier asedio al problema de la recepción clariniana del teatro áureo debía tener en cuenta no solo sus imágenes del naturalismo malentendido como inevitable "infección" del añorado legado áureo, sino que también debía ocuparse del estigma barroco en su vínculo con lo imperial y, por lo tanto, con la "viruela" como metáfora. A esto último dedicaré entonces unas reflexiones finales.

Marzo inicia su ensayo La memoria administrada. El barroco y lo hispano con una alusión a Benjamin donde explica que el filósofo alemán vio justamente en el barroco la posibilidad de sustraerse a ciertas quimeras de la modernidad, pero que sin embargo advertía: "cuidado con la máquina, porque se necesita una vacuna para no quedar atrapado en ella. Y cuidado con la vacuna, porque una dosis equivocada te hace barroco" (Marzo 9). El barroco puede percibirse, según Marzo, como elemento antimoderno cuyo contagio es siempre inminente en la cercanía. Cuando explica el concepto del barroco como táctica de control imperial, analiza la cualidad que se autoadjudicaban los nativos americanos al calificarse como nepantla, "o sea, en medio, en ningún sitio, entre el aquí y el allá” (103), término que

...lo que intenta transmitir es la urgencia de no vivir sometido a la arbitrariedad de los nuevos amos, de los nuevos dioses, de las misteriosas enfermedades; la necesidad de conocer el papel que se espera de ellos y el contenido del texto que deben interpretar (103). 
El barroco no es independiente de la exigencia de esa teatralidad que los conquistados sienten ante los conquistadores. Es esperable, en este sentido, que Alas compare a Calvo, el gran embajador del teatro barroco, con aquellos hombres que llegaron a América trayendo la imposición de la hispanidad: "Sí; Rafael, que años adelante había de recorrer la América, que conquistaron nuestros colosales españoles de las grandes aventuras, recogiendo, sin lucha, laureles de victorias artísticas, pudo haber sido, de nacer otros días, un Pizarro, un Cortés..." (Alas, Rafael). Es sugestivo que Alas traiga a colación la figura de los conquistadores, portadores emblemáticos de la hispanidad hacia América, pero también de la "viruela", no tanto como enfermedad, sino como símbolo de un Imperio cuya modernidad se retrae incluso hasta asignarse las culpas heredadas a sus propios hijos. Porque ese intérprete que es Calvo, y que según Clarín "cantaba el ideal del amor, del honor y de la patria en el octosílabo inmortal de nuestros grandes dramaturgos" (Alas, Rafael), no solo lleva consigo el teatro áureo a América sino que vuelve de ella con el mal que esos conquistadores -que él mismo podría haber sido de nacer en otro tiempo- llevaron a América mucho tiempo antes de que el teatro áureo esplendiera. La viruela como metáfora se vuelve polisémica en el cuerpo de Calvo: el ensayismo de Alas propone un cuerpo mortal para cantar el verso inmortal; y justamente en la mortalidad de ese cuerpo se conjuga el conflicto literario entre el pasado y el futuro español. En el rostro envenenado de Calvo contiende la viruela naturalista de Naná y la viruela imperial de los conquistadores arribados a América. El símbolo parece estallar en significados bifrontes y el sentido que se construye no es menor en un texto crítico donde Alas prioriza, a partir de la figura simbólica del gran actor español, la situación conflictiva entre la tradición teatral del Siglo de Oro y su agonía frente a la renovación dramática adeudada por la modernidad del siglo XIX.

Tal como afirmaba Díaz Plaja y recoge Marzo en su análisis del barroco y la hispanidad:

"Entre nosotros todo clasicismo está como a precario, difícilmente huido de lo que fue y amenazado de lo que va a venir, y aún minado por secretos microbios de lo personal, de lo torturado y de lo insatisfecho". Estos son los ingredientes que hacen posible la salsa barroca: un hombre desubicado, alergias a la simetría y la necesidad de disponer de un espacio mítico en el que encontrar consuelo (133).

El espíritu barroco -y su teatro como espacio literario privilegiado-, parece resultar entonces un territorio mítico de la hispanidad, un refugio a 
donde replegarse con los "microbios" de la personalidad desubicada por la incertidumbre del futuro. Marzo insiste en el barroco como una especie de "vacuna contra la modernidad". Y en este sentido afirma: "Cada uno hace de la historia aquello que quiere justificar en el presente" (217). Si bien este argumento es más reconocible para el caso de lo barroco colonial, no es menos cierto que la operación sobre el pasado como modelo regulador de la energía renovadora del presente se cumple también en otras aristas de la hispanidad y es fácilmente observable en un tema como el del teatro áureo y su recepción al borde del siglo XX. La propia crítica de Alas se debate-desde su temprano volumen Solos-, entre el elogio del pasado y la desesperada incógnita sobre la renovación moderna: "Nadie como yo, o más que yo, para decirlo exactamente, ama y admira aquel teatro del siglo XVII (...). Todo eso es divina poesía (...); pero nada de eso es lo que hoy ha de buscar la musa dramática..." (Alas, Solos 53-54).

En esta misma línea vale destacar que tanto en Clarín como en Pardo Bazán y en otros intelectuales de la época, es la llegada de modelos foráneos la que presiona la modernización del drama español, al mismo tiempo que el nacionalismo cultural obliga por su parte a la custodia de la autoridad pretérita, de la "restauración" de los genios barrocos ante la inminencia de lo moderno. Esto es lo que sin dudas nutre de manera tan intensa la retórica crítica de fin de siglo cada vez que hay que cotejar la renovación de la praxis dramática y el respeto a la tradición teatral áurea. Esta contradicción es, a su vez, la que viene a legitimar de modo bifronte una crítica higiénica como la que postula en su especificidad el modelo clariniano y que se erige básicamente como usina de difusión de un discurso de control policíacosanitario. Resuenan en el carácter deseable de esa crítica según Clarín los mismos presupuestos discursivos que Foucault supo ver en la prevención clínica de enfermedades ya en el siglo XVIII. No habría medicina -señala el pensador francés- si no estuviera reforzada por una policía. Y evoca al respecto un texto prerrevolucionario donde se sugieren medidas puntuales contra las epidemias, y donde se aspira a la concreción de "un reglamento de salud para leerse 'en el sermón o en la misa, todos los domingos y fiestas' y que hiciera referencia a la manera de alimentarse, de vestirse, de evitar las enfermedades" (Foucault 50). Hay algo de ese "reglamento" preventivo que late bajo los perfiles de la crítica clariniana -del "sermón perdido" de Alas-, sobre todo en cuanto ronda desde el fin del siglo XIX el objeto puntual del teatro áureo y revela allí su doble "viruela": la melancólica del pasado y la incierta del futuro, y entre ambas la controvertida apreciación de una España imperial agonizante. 
Porque la conquista imperial, en esta dirección, sigue siendo el relato implícito que porta la clave para comprender las contradicciones de la crítica hispánica moderna. La irradiación de la hispanidad en América, explica Marzo, está dada en cierto modo por la ambigüedad del lema jesuita "ite et inflamate". Ignacio de Loyola manda esto en su testamento: "id e incendiad", lo que no solo invita a inflamar y ganar la fe de los "otros", sino que también describe un tiempo de enfrentamientos lamentables cuya historia antecede al testimonio cultural de un teatro fundacional para la identidad de ese proyecto imperial. Por eso recuerda Marzo que también "es el tiempo en que los indios sufrían una hecatombe demográfica entre llagas purulentas de viruela y la brutal presión de mineros y encomenderos españoles, ya dueños y señores del imperio" (325). Este señalamiento no parece menor, sobre todo en un circuito donde la idea de lo barroco - condensada muchas veces en el núcleo de su teatro oficial-, persiste una y otra vez en tensionar el concepto de modernidad y sus implicancias renovadoras. En este sentido, sostengo una vez más, que la revelación de ciertas metáforas de la enfermedad les permitió a Clarín y a otros intelectuales españoles a fines del siglo XIX contemplar de manera bifronte, pero extremadamente comprometida, la contienda inevitable entre el canon legitimado y la renovación inminente; entre la restauración del modelo cultural de la nación y la aparición de aportes foráneos novedosos; entre el teatro del Siglo de Oro, en definitiva, y el abanico amplio de procedimientos naturalistas con su hegemonía por entonces naciente.

\section{BIBLIOGRAFÍA}

Alas, Leopoldo. Palique. Obras completas. Tomo II. Madrid: RBA, 2008.

Ensayos y revistas: 1888-1892. Biblioteca Virtual Miguel de Cervantes 2002 (edición digital basada en la de Madrid, Manuel Fernández Lasanta, 1892), http://www. cervantesvirtual.com/obra/ensayos-y-revistas-18881892--0/, revisado el 26/4/2015.

Palique. Biblioteca Virtual Miguel de Cervantes 2001 (edición digital basada en la de Madrid, Librería de Victoriano Suárez, 1893) http://www.cervantesvirtual.com/obra/ palique--1/, revisado el 26/4/2015.

Sermón perdido. Biblioteca Virtual Miguel de Cervantes 2001 (edición digital basada en la de Madrid, Librería de Fernando Fé, 1885) http://www.cervantesvirtual. com/obra/sermon-perdido-critica-y-satira--0/, revisado el 26/4/2015.

Rafael Calvo y el teatro español. Biblioteca Virtual Miguel de Cervantes 2000 (edición digital basada en la de Madrid, Librería de Fernando Fe, 1890) http://www. cervantesvirtual.com/obra/rafael-calvo-y-el-teatro-espanol--0/, revisado el 26/4/2015.

Solos de clarín. Madrid: Alianza Ed. 1971. 
Ezama Gil, Ángeles. "Un artículo olvidado de «Clarín» sobre María Guerrero". Boletín del Instituto de Estudios Asturianos no 130 (1989): 263-274.

Fernández Almagro, Melchor. "José Calvo, Rafael Calvo, Ricardo Calvo...”, ABC 2015 (edición digital basada en la impresa en Madrid, 26/01/1956) http://hemeroteca.abc.es/, revisado el 16/4/2015.

Foucault, Michel. El nacimiento de la clínica. Una arqueología de la mirada médica. Buenos Aires: Siglo XXI, 2014.

Guastavino, Guillermo. “Algo más sobre Clarín y Teresa”. Bulletin Hispanique LXXIII, nros. 1 у $2,(1971): 133-159$.

López Quintáns, Javier. "Brillo de candilejas: Emilia Pardo Bazán, Benito Pérez Galdós, Clarín y el teatro". Estudios humanísticos. Filología 34 (2012): 169-186.

Martínez Cachero, José María. "Noticia del estreno de Teresa («ensayo dramático en un acto y en prosa, original de D. Leopoldo Alas», 1895) y de algunas críticas periodísticas". Archivum, tomo XIX (1969): 243-273.

Marzo, Jorge Luis. La memoria administrada. El barroco y lo hispano. Madrid: Katz Ed. 2010.

Pardo Bazán, Emilia. La cuestión palpitante. Biblioteca Virtual Miguel de Cervantes, 2000 (edición digital a partir de Obras completas. Tomo I. Madrid, Imprenta de A. Pérez Dubrull, 1891), http://www.cervantesvirtual.com/obra/la-cuestion-palpitante--0/, revisado el 16/4/2015.

La cuestión palpitante. Salamanca: Anaya, 1966.

"La nueva cuestión palpitante VI. Digresión”. Los Lunes de El Imparcial (3/7/1894): 1.

"La nueva cuestión palpitante IV. La base racional”. Los Lunes de El Imparcial (2/7/1894): 1 .

"La nueva cuestión palpitante III. La base experimental". Los Lunes de El Imparcial (11/6/1894): 1 .

Pozuelo Yvancos, José María. "Popular/culto, genuino/foráneo: canon y teatro nacional español". Theatralia III. Tragedia, comedia, canon. (III Congreso Internacional de Teoría del Teatro, 2000). Vigo: Universidad, Facultad de Filología y Traducción, Ediciones del Área de Teoría de la Literatura (2000): 235 - 260.

Richmond, Carolyn. "Clarín y el teatro: el cuento de un crítico". Los Cuadernos del Norte. Revista Cultural de la Caja de Ahorros de Asturias, año II, n 7, (mayo-junio 1981): 56-67.

Rodríguez Puértolas, Julio. Literatura fascista española. Madrid: Akal, 1986.

Sontag, Susan. La enfermedad y sus metáforas. El sida y sus metáforas. Buenos Aires: Taurus, 2003.

Sotelo Vázquez, Adolfo. "Los discursos del Naturalismo en España". Actas del I Coloquio de la Sociedad de Literatura Española del Siglo XIX (Barcelona, 24-26 de octubre de 1996). Del Romanticismo al Realismo. Eds. Luis F. Díaz Larios y Enrique Miralles. Barcelona. Barcelona: Universitat (1998): 455-465.

Zola, Émile. "El naturalismo en el teatro". El naturalismo. Barcelona: Ed. Península (2002): 144-193.

Obras estelares. La taberna. Naná. Barcelona: Ed. Maucci S. L., 1963. 